\title{
Revision of Alnus (Betulaceae) in Iran using molecular ITS markers and morphological characteristics
}

Tahereh Gholamiterojeni ${ }^{1}$,

Fariba Sharifnia $^{2, *}$,

Taher Nejadsattari ${ }^{3}$,

Mostafa Assadi ${ }^{4}$,

Seyed Mohammad Mehdi Hamdi ${ }^{5}$

${ }^{1,3}$ Department of Biology,

Science and Research Branch,

Islamic Azad University,

Tehran, Iran

${ }^{2}$ Department of Biology,

Tehran North Branch,

Islamic Azad University,

Vafadar Blvd.,

Shahid Sadoughi St.,

Hakimiyekh Exit, Tehran, Iran

${ }^{4}$ Research Institute of Forests and Rangelands,

Agricultural Research Education and Extension Organization (AREEO),

District 22, Pajoohesh Blvd.,

Tehran, Iran

${ }^{5}$ Department of Biology,

Central Tehran Branch,

Islamic Azad University,

Asharafi Esfahari St.,

Poonak, Tehran, Iran
Alnus (Alder) is a genus of Betulaceae, which comprises more than 29 species in the world. According to different classifications of flora, eight taxa of the genus naturally grow in Iran and are distributed along the northern slope of Albourz Mountains in Iran (Hyrcanian forests). In the current research, we investigated morphological characteristics and phylogenetic relationships of 31 populations of the genus in Iran. Twenty-eight qualitative and quantitative traits were studied for morphological evaluation and ITS molecular marker was investigated for molecular study. We used MVSP, SPSS, MrBayes, RAXMLGUI, Mesquite 2.71, Modeltest 3.7 software packages for statistical analyses. Morphological features varied widely among the studied taxa and ANOVA test revealed significant difference for most of them. Moreover, the angle of leaf base, the leaf margin shape, the length and width of the leaf blade, fruits length, and the presence of hair on the petioles, young twigs, and buds were more variable morphological traits. The studied taxa were clustered separately in the UPGMA tree, PCA and PCO plots using morphological traits. In addition, CA-joined plot showed each taxon to have distinct morphological trait(s), which is useful in the identification of the taxa. Phylogeny analysis revealed that Alnus genus is a monophyletic group. Furthermore, the studied taxa were clustered separately in phylogenetic dendrogram. According to morphological and ITS data, we listed ten taxa of the genus in Iran and introduced A. hyrcana and A. longiflorescentia as two new species from Hyrcanian forests of Iran.

Keywords: Alnus, Hyrcanian forests, Iran, ITS, new species, morphology

\footnotetext{
* Corresponding author: faribasharifnia2234@gmail.com,

f_sharifnia@iau-tnb.ac.ir
} 


\section{INTRODUCTION}

Alnus Mill. is the genus of Betulaceae and contains about $29-35$ species that are mainly distributed across Asia, Africa, Europe, and North America (Murai, 1964; Furlow, 1979; Frodin, Govaers, 1998). Moreover, in Iran, the northern slopes of Albourz Mountains that belong to Euxino-Hyrcanian district are covered with temperate deciduous forests (Zohary, 1973). Alnus species forms about $6.7 \%$ of these forests in the country (Sagheb-Talebi, 2004).

Sati et al. (2011) believe that several species of the genus are commonly used in traditional medicines. For example, Alnus hirsuta Turcz. has been used in oriental medicine as a remedy for fever, haemorrhages, burn injuries, diarrhoea, and alcoholism (Park et al., 2010).

Different studies (Lee et al., 1992; Novaković et al., 2013) proved that several bioactive natural components including diarylheptanoids, polyphenols, flavonoids, terpenoids, and steroids, were isolated from Alnus species. Hu and Wang (2011) suggested that diarylheptanoids were considered as the primary bioactive compounds of Alnus taxa and attracted attention due to their physiological activities such as anticancer and antioxidative activities.

There are many discussions about the number of Alnus species in Iran. For example, Boissier (1879) reported the presence of four taxa including A. glutinosa Willd, A. incana Willd, A. cordifoliaa Ten, and A. orientalis Decne in the Flora Orientalis. Browicz (1972) listed three taxa, namely, A. glutinosa subsp. barbata (C. A. Mey.) Yalt., A. subcordata var. villosa (Regel) H. J. P. Winkl., and A. subcordata C. A. Mey. var. subcordata in Flora Iranica.

Moreover, Mobayen (1985) reported the presence of two species, A. glutinosa and A. subcordata, in Iranian Flora. Kuzeneva (1936) reported 12 taxa of Alnus in Flora U.S.S.R. More recently, Zare and Amini (2012) introduced five taxa, namely, A. dolichocarpa H. Zare, Amini \& Assadi, A. djavanshirii H. Zare, A. glutinosa subsp. glutinosa (L.) Gaertn., A. glutinosa subsp. antitaurica Yalt, and $A$. orientalis Decne from Iran. How- ever, Shayanmehr et al. (2014) doubted the presence of $A$. orientalis, $A$. dolichocarpa, and $A$. djavanshirii in Iran because of morphological similarities to A. subcordata.

Hoseinzadeh et al. (2016) investigated the phylogenetic relationships of eight taxa of Iranian Alnus using ITS and trnH-psbA. The trnH-psbA chloroplast marker showed lesser separability in comparison with ITS. A. dolichocarpa, A. djavanshirii, and A. orientalis are morphologically very similar to A. subcordata, therefore, their taxonomic status is unknown and their presence in the Hyrcanian region is doubted.

It seems that investigation of molecular phylogeny of this genus is a very good and useful approach that may help resolve these taxonomical and evolutionary questions. However, Savard et al., (1993) reported that Betulaceae appeared to be slow-evolving taxa at the DNA level, while the nuclear ribosomal internal transcribed spacer sequences (ITS) were more variable than chloroplast $r b c L$ sequences, with potentially useful phylogenetic signal at the genus level. Therefore, in the current study we revised Iranian Alnus species using morphological and phylogenetic method (ITS) in order to determine the number of its species in Iran.

\section{MATERIALS AND METHODS}

\section{Plant samples}

Considering the distribution range of Alnus species in Iran, sampling was done in 21 stations from the northern slope of Albourz Mountains at different altitudes of Hyrcanian forests (Table 1). Based on the geographical distribution, one to three populations of each taxon were selected. Plant specimens were identified according to descriptions provided in valuable references such as Flora Orientalis (Boissier, 1879), Flora Iranica (Browicz, 1972), Flora U.S.S.R (Kuzeneva, 1936), Flora Turkey (Yaltrik, 1982) and Flora of Iran (Zare, 2016). Herbarium samples were placed in the herbarium of Tehran North Branch, Islamic Azad University (IAUNT). 
Table 1. Locality addresses of the studied Alnus samples collected from different localities of Hyrcanian forests

\begin{tabular}{|c|c|c|c|c|}
\hline Taxa & Locality & Geographic coordinates & Elevation $(\mathrm{m})$ & Herbarium no. \\
\hline A. hyrcana & Golestan-National park & $37^{\circ} 23^{\prime} 43.62^{\prime \prime} \mathrm{N}, 55^{\circ} 48^{\prime} 1.5^{\prime \prime} \mathrm{E}$ & 471 & 16720 IAUNT \\
\hline A. subcordata var. subcordata & Golestan-Ramin & $36^{\circ} 59^{\prime} 47.8^{\prime \prime} \mathrm{N}, 55^{\circ} 9^{\prime} 59^{\prime \prime} \mathrm{E}$ & 362 & 16725 IAUNT \\
\hline A. subcordata var. subcordata & Golestan-Gorgan & $36^{\circ} 46^{\prime} 18.17^{\prime \prime} \mathrm{N}, 54^{\circ} 28^{\prime} 3.94^{\prime \prime} \mathrm{E}$ & 477 & 16727 IAUNT \\
\hline A. subcordata var. subcordata & Mazandaran-Rooyan & $36^{\circ} 34^{\prime} 14.38^{\prime \prime} \mathrm{N}, 51^{\circ} 53^{\prime} 3.26^{\prime \prime} \mathrm{E}$ & -7 & 16737 IAUNT \\
\hline A. subcordata var. villosa & Mazandaran-Gelvard & $36^{\circ} 35^{\prime} 03.80^{\prime \prime} \mathrm{N}, 53^{\circ} 36^{\prime} 23.57^{\prime \prime} \mathrm{E}$ & 753 & 16732 IAUNT \\
\hline A. subcordata var. villosa & Mazandaran-Sangedeh & $36^{\circ} 04^{\prime} 05.63^{\prime \prime} \mathrm{N}, 53^{\circ} 13^{\prime} 01.93^{\prime \prime} \mathrm{E}$ & 1281 & 16733 IAUNT \\
\hline A. longiflorescentia & Golestan-Gorgan & $36^{\circ} 7^{\prime} 7.7^{\prime \prime} \mathrm{N}, 53^{\circ} 3^{\prime} 20.8^{\prime \prime} \mathrm{E}$ & 640 & 16719 IAUNT \\
\hline A. djavanshirii & Mazandaran-Behshahr & $36^{\circ} 39^{\prime} 27.87^{\prime \prime} \mathrm{N}, 53^{\circ} 30^{\prime} 26.87^{\prime \prime} \mathrm{E}$ & 443 & 16729 IAUNT \\
\hline A. orientalis & Mazandaran-Neka & $36^{\circ} 34^{\prime} 15.54^{\prime \prime} \mathrm{N}, 53^{\circ} 29^{\prime} 14.65^{\prime \prime} \mathrm{E}$ & 478 & 16731 IAUNT \\
\hline A. orientalis & Mazandaran-Sisangan & $36^{\circ} 35^{\prime} 6.3^{\prime \prime} \mathrm{N}, 51^{\circ} 47^{\prime} 24.36^{\prime \prime} \mathrm{E}$ & -6 & 16738 IAUNT \\
\hline A. glutinosa ssp. glutinosa & $\begin{array}{c}\text { Mazandaran-Rostam- } \\
\text { rood }\end{array}$ & $36^{\circ} 35^{\prime} 35^{\prime \prime} \mathrm{N}, 52^{\circ} 6^{\prime} 25.18^{\prime \prime} \mathrm{E}$ & -30 & 16735 IAUNT \\
\hline A. glutinosa ssp. glutinosa & Mazandaran-Chaloos & $36^{\circ} 41^{\prime} 16.82^{\prime \prime} \mathrm{N}, 51^{\circ} 18^{\prime} 29.42^{\prime \prime} \mathrm{E}$ & -29 & 16741 IAUNT \\
\hline A. glutinosa ssp. glutinosa & Mazandaran-Chaboksar & $36^{\circ} 57^{\prime} 59.5^{\prime \prime} \mathrm{N}, 50^{\circ} 35^{\prime} 12.94^{\prime \prime} \mathrm{E}$ & -10 & 16743 IAUNT \\
\hline A. glutinosa ssp. antitaurica & Gilan-Astara & $38^{\circ} 25^{\prime} 20^{\prime \prime} \mathrm{N}, 48^{\circ} 52^{\prime} 27.28^{\prime \prime} \mathrm{E}$ & -22 & 16750 IAUNT \\
\hline A. glutinosa ssp. antitaurica & Mazandaran-Chaboksar & $37^{\circ} 3^{\prime} 54^{\prime \prime} \mathrm{N}, 50^{\circ} 25^{\prime} 25.9^{\prime \prime} \mathrm{E}$ & -45 & 16744 IAUNT \\
\hline A. glutinosa ssp. antitaurica & $\begin{array}{l}\text { Mazandaran-Mahmood- } \\
\text { abad }\end{array}$ & $36^{\circ} 36^{\prime} 45.9^{\prime \prime} \mathrm{N}, 52^{\circ} 12^{\prime} 7.66^{\prime \prime} \mathrm{E}$ & -20 & 16734 IAUNT \\
\hline A. glutinosa ssp. barbata & Gilan-Talesh & $37^{\circ} 41^{\prime} 3.42^{\prime \prime} \mathrm{N}, 48^{\circ} 59^{\prime} 49.59^{\prime \prime} \mathrm{E}$ & 13 & 16751 IAUNT \\
\hline A. glutinosa ssp. barbata & Gilan-Astane Ashrafiye & $37^{\circ} 14^{\prime} 59.29^{\prime \prime} \mathrm{N}, 49^{\circ} 56^{\prime} 54.65^{\prime \prime} \mathrm{E}$ & -12 & 16745 IAUNT \\
\hline A. glutinosa ssp. barbata & Mazandaran-Noshahr & $36^{\circ} 38^{\prime} 18.77^{\prime \prime} \mathrm{N}, 51^{\circ} 30^{\prime} 51.23^{\prime \prime} \mathrm{E}$ & -5 & 16739 IAUNT \\
\hline A. dolichocarpa & Gilan-Astara & $38^{\circ} 12^{\prime} 33.63^{\prime \prime} \mathrm{N}, 48^{\circ} 53^{\prime} 10.54^{\prime \prime} \mathrm{E}$ & -10 & 16749 IAUNT \\
\hline A. dolichocarpa & Mazandaran-Noshahr & $36^{\circ} 38^{\prime} 27.8^{\prime \prime} \mathrm{N}, 51^{\circ} 28^{\prime} 29.96^{\prime \prime} \mathrm{E}$ & -8 & 16740 IAUNT \\
\hline
\end{tabular}

\section{Morphological studies}

Measurements of morphological traits were performed on each plant, including its flowering stem. In total, 28 qualitative and quantitative features from both vegetative and reproductive organs were measured on each specimen. Each character was measured four times per each plant sample. Three individuals were studied per each population and the average of each trait was determined. The 17 studied quantitative morphological characteristics were the length and the width of the leaf blade, the length of petiole, the number of lateral vein pairs, the length and width of the male catkin, the number of male catkins on one twig, the length and width of fruits, the length of the pedicel of male and female catkin, the number of fruits (cone) on one twig, the number of teeth in the upper third of the leaf, the distance from the base of the leaf blade to its widest part, the distance from the top of the leaflet to the top of the upper third vein, the angle from the top of the leaf to the top of the upper third nerve, and the angle of the leaf base. In addition, eleven qualitative evaluated features were the leaf base, the apex and margin shape, leaf symmetry, the cone form, the presence of hair on the fruit stalk, annual branch, buds, upper and lower surfaces of leaves, and the branching point. 


\section{Statistical analyses}

We subjected the quantitative data to one-way analysis of variance (ANOVA) to determine if significant variation existed among the studied taxa for each characteristic measured. Mean and standard deviations of features were calculated. These analyses were performed using SPSS software. Cluster analysis was carried out based on quantitative and qualitative variables using UPGMA tree, PCO, PCA and CA-Joined plots clustering in Multivariate Statistical Package (MVSP) program (Podani, 2000).

\section{DNA extraction, PCR, and sequencing}

From the collected plants, three leaf samples were stored in silica gel for molecular study. Genome extraction was performed using the MBST Kit (Shayan et al., 2007) according to the instructions of the manufacturer. PCR was done for DNA amplification in a total volume of $25 \mu \mathrm{l}(3 \mu \mathrm{l}$ DNA sample, $12.5 \mu \mathrm{l}$ Master Mix RED, and $0.5 \mu$ of forward and reverse primers, $1 \mu \mathrm{l}$ DMSO and $7.5 \mu l$ deionized water (Table 2). PCR product was tested by 0.1 agarose gel. Sequencing and purification of PCR product were carried out by Sectech Co.

\section{Phylogenetic analysis}

Sequences processing was performed with Sequencer 4.1.4 software. Betula pendula Roth was considered as out group (its sequence was selected in the GenBank) (Table 3). The sequences were aligned using the Mesquite 2.71 software. The Nexus file was analyzed with Modeltest 3.7 software. The best evolutionary model for the tenth generation was selected and analyzed. The final cladogram was drawn with MrBayes 3.1.2 and raxmlGUI software.

Table 2. Sequences of ITS primers

\begin{tabular}{c|c|c|c}
\hline Primer name & Primer sequences & PCR conditions & References \\
\hline \multirow{2}{*}{ AB101 } & $5^{\prime}$-ACGAATTCATGGTCCGGT- & $95^{\circ} \mathrm{C} \mathrm{5} ; 35$ cycles; & \\
& GAAGTGTTCG-3' & $95^{\circ} \mathrm{C} 30^{\prime \prime} ; 57.5^{\circ} \mathrm{C} 30^{\prime \prime} ;$ & Douzery et al., 1999 \\
\cline { 1 - 2 } AB102 & $5^{\prime}$-TAGAATTCCCCGGTTCGCTC- & $72^{\circ} \mathrm{C} 1.5^{\prime} ; 72^{\circ} \mathrm{C} 7^{\prime}$ & \\
\hline
\end{tabular}

Table 3. GenBank accession numbers used in the molecular analysis of the ITS marker

\begin{tabular}{cccc}
\hline Species & GenBank accession numbers & Species & GenBank accession numbers \\
\hline A. mandschurica & AY352315 & A. nepalensis & AY352318 \\
\hline A. sinuata & AY352325 & A. ferdinandi-coburgii & FJ825416 \\
\hline A. maximowiczii & AB243877 & A. cremastogyne & FJ825413 \\
\hline A. fruticosa & AY352309 & A. cordata & AJ251663 \\
\hline A. crispa & AJ251681 & A. trabeculosa & FJ825408 \\
\hline A. viridis & AY352329 & A. henryi & GU112748 \\
\hline A. pendula & AJ251682 & A. oblongifolia & AY352319 \\
\hline A. sieboldiana & FJ825384 & A. rhombifolia & AJ251669 \\
\hline A. firma & FJ825381 & A. acuminata & AF432066 \\
\hline A. formosana & AJ251678 & A. jorullensis & AJ251672 \\
\hline A. maritima & AJ251679 & A. matsumurae & FJ825397 \\
\hline A. serrulatoides & FJ825428 & A. tenuifolia & AJ251666 \\
\hline A. fauriei & FJ825433 & A. rugosa & AY352313 \\
\hline A. japonica & FJ825425 & A. hirsuta & FJ825389 \\
\hline A. serrulata & AY352322 & A. incana & FJ8251665 \\
\hline A. nitida & AJ783638 & A. rubra \\
\hline Betula pendula & AY352332 &
\end{tabular}




\section{RESULTS}

\section{Morphological analysis}

The mean and standard deviation of some quantitative morphological variables are presented in Table 4. Morphological characteristics high- ly varied among the studied taxa. For example, the smallest and the largest blade leaf length was recorded in A. glutinosa subsp. antitaurica and $A$. djavanshirii, respectively. The narrowest blade leaf was found in A. subcordata var. villosa, while the broadest one was observed

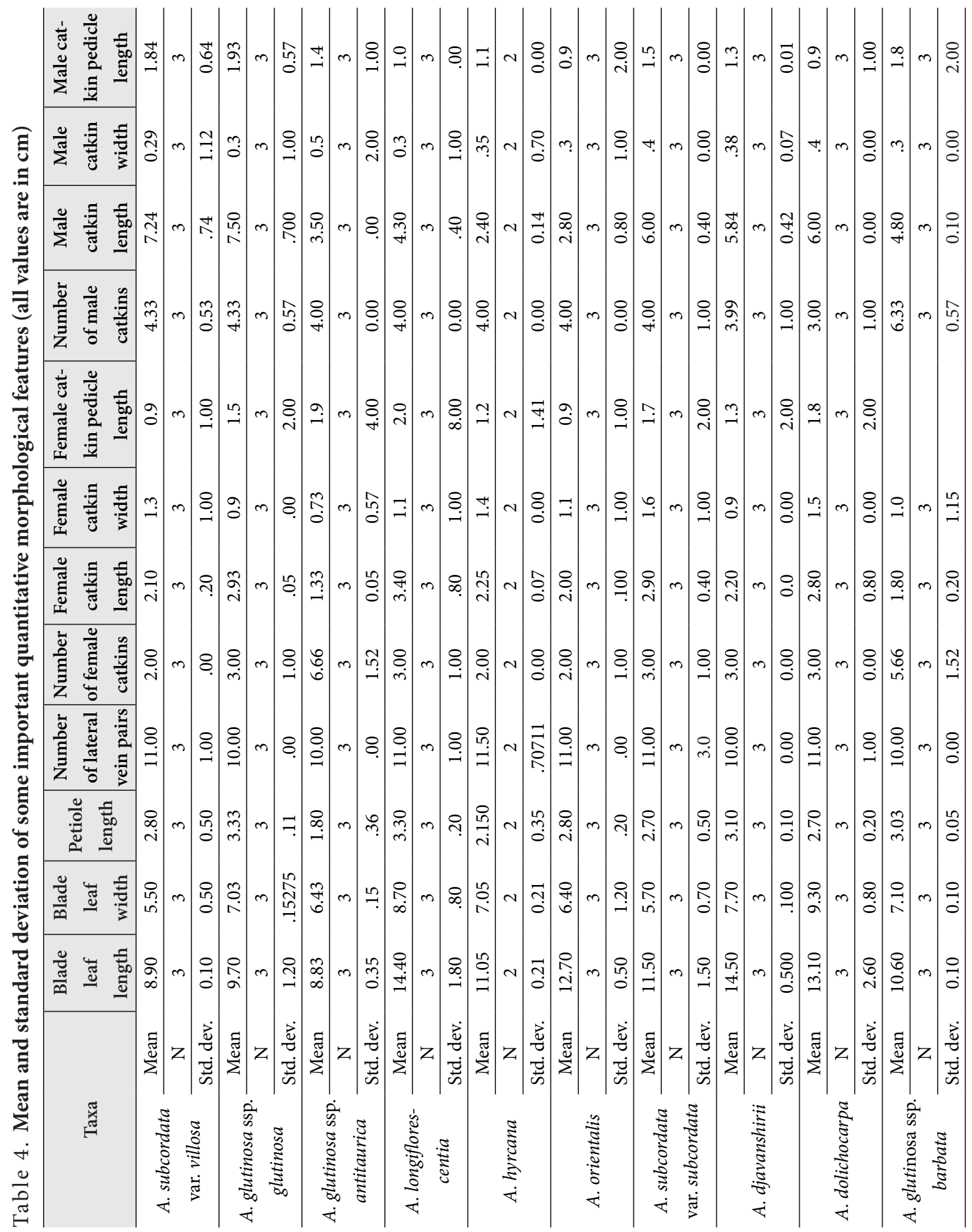


in A. dolichocarpa. The shortest and the largest petioles were registered in A. glutinosa subsp. antitaurica and A. longiflorescentia. The biggest number of female catkins (6.66) belonged to A. glutinosa subsp. antitaurica, but most of the studied taxa had two and three female catkins. A. longiflorescentia had the longest female catkin, while A. glutinosa subsp. antitaurica had the shortest female catkin. Moreover, the widest female catkin was recorded in A. subcordata var. subcordata, but A. glutinosa subsp. antitaurica had the narrowest female catkin.

The ANOVA test revealed significant difference for all quantitative morphological char- acteristics, except for the width of the male catkin and the number of lateral vein pairs (Table 5).

The studied taxa separated from each other and were clustered separately in the UPGMA tree of morphological data (Fig. 1); moreover, PCO and PCA plots (Fig. 2, 3) produced similar outputs. Therefore, taxa arrangements in the tree were discussed here: the tree had two branches. The small branch divided into two sub-branches. A. djavanshirii were placed in a sub-branch, while three varieties of $A$. subcordata existed in another sub-branch, which had two groups. A. glutinosa subsp. glutinosa and

Table 5. Results of the ANOVA test among the studied quantitative features

\begin{tabular}{|c|c|c|c|c|c|c|}
\hline & & Sum of squares & Difference & Mean square & $\mathrm{F}$ & Sig. \\
\hline \multirow{3}{*}{ Blade leaf length } & Between groups & 118.340 & 9 & 13.149 & 8.701 & 0.0 \\
\hline & Within groups & 28.712 & 19 & 1.511 & & \\
\hline & Total & 147.052 & 28 & & & \\
\hline \multirow{3}{*}{ Blade leaf width } & Between groups & 39.660 & 9 & 4.407 & 11.795 & 0.0 \\
\hline & Within groups & 7.098 & 19 & .374 & & \\
\hline & Total & 46.759 & 28 & & & \\
\hline \multirow{3}{*}{ Petiole length } & Between groups & 5.940 & 9 & .660 & 7.472 & 0.0 \\
\hline & Within groups & 1.678 & 19 & .088 & & \\
\hline & Total & 7.619 & 28 & & & \\
\hline \multirow{3}{*}{ Number of lateral vein pairs } & Between groups & 8.328 & 9 & .925 & .718 & 0.687 \\
\hline & Within groups & 24.500 & 19 & 1.289 & & \\
\hline & Total & 32.828 & 28 & & & \\
\hline \multirow{3}{*}{ Number of female catkins } & Between groups & 65.494 & 9 & 7.277 & 7.977 & 0.0 \\
\hline & Within groups & 17.333 & 19 & .912 & & \\
\hline & Total & 82.828 & 28 & & & \\
\hline \multirow{3}{*}{ Female catkin length } & Between groups & 10.475 & 9 & 1.164 & 7.184 & 0.0 \\
\hline & Within groups & 3.078 & 19 & .162 & & \\
\hline & Total & 13.553 & 28 & & & \\
\hline \multirow{3}{*}{ Female catkin width } & Between groups & 211.908 & 9 & 23.545 & 39.473 & 0.0 \\
\hline & Within groups & 11.333 & 19 & .596 & & \\
\hline & Total & 223.241 & 28 & & & \\
\hline \multirow{3}{*}{ Female catkin pedicle length } & Between groups & 406.615 & 8 & 50.827 & 4.364 & 0.005 \\
\hline & Within groups & 198.0 & 17 & 11.647 & & \\
\hline & Total & 604.615 & 25 & & & \\
\hline \multirow{3}{*}{ Male catkin width } & Between groups & 11.152 & 7 & 1.593 & 1.648 & 0.197 \\
\hline & Within groups & 14.500 & 15 & .967 & & \\
\hline & Total & 25.652 & 22 & & & \\
\hline \multirow{3}{*}{ Male catkin length } & Between groups & 59.815 & 7 & 8.545 & 43.597 & 0.0 \\
\hline & Within groups & 2.940 & 15 & .196 & & \\
\hline & Total & 62.755 & 22 & & & \\
\hline \multirow{3}{*}{ Male catkin pedicle length } & Between groups & 367.942 & 7 & 52.563 & 38.151 & 0.0 \\
\hline & Within groups & 20.667 & 15 & 1.378 & & \\
\hline & Total & 388.609 & 22 & & & \\
\hline \multirow[t]{3}{*}{ Number of male catkin } & Between groups & 18.580 & 7 & 2.654 & 7.465 & 0.001 \\
\hline & Within groups & 5.333 & 15 & .356 & & \\
\hline & Total & 23.913 & 22 & & & \\
\hline
\end{tabular}



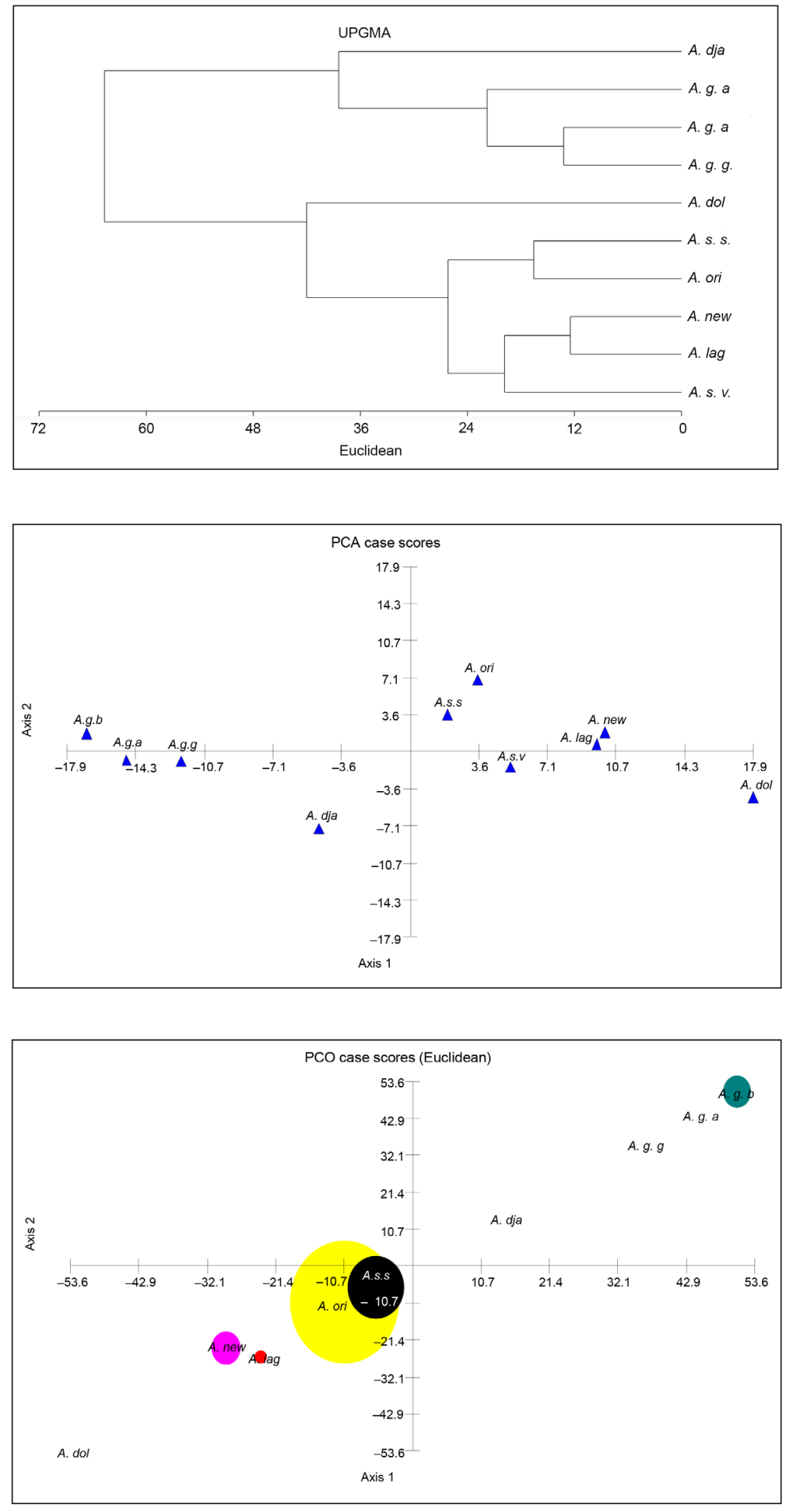

Fig. 1. The UPGMA tree of the studied taxa based on morphological traits. Abbreviations: A. $g \cdot g=A$. glutinosa subsp. glutinosa; $A$. g.b $=$ A. lutinosa subsp. barbata; A. g.a = A. glutinosa subsp. antitaurica; $A$. s.s $=A$. subcordata var. subcordata; A. s.v $=A$. subcordata var. villosa; $A$. ori $=A$. orientalis; A. dol = A. dolichocar$p a ; A . \quad d j a=A$. djavanshirii; A. $\operatorname{lag}=A$. longiflorescentia; A. New $=$ A. hyrcana

Fig. 2. PCA plot of the studied taxa based on morphological variables. Abbreviations: A. g.g $=$ A. glutinosa subsp. glutinosa; $A$. g.b = A. glutinosa subsp. barbata; A. g.a $=$ A. glutinosa subsp. antitaurica; A. s.s. $=$ A. subcordata var. subcordata; A. s.v = A. subcordata var. villosa; A. ori $=$ A. orientalis; A. dol $=$ A. dolichocarpa; $A$. dja $=A$. djavanshirii; $A$. lag = A. longiflorescentia; A. New $=$ A. hyrcana

Fig. 3. PCO plot of the studied taxa based on morphological characteristics. Abbreviations: A. $g \cdot g=A \cdot$ glutinosa subsp. glutinosa; A. g.b $=$ A. glutinosa subsp. barbata; A. g.a $=$ A. glutinosa subsp. antitaurica; $A$. s.s $=$ A. subcordata var. subcordata; $A$. s.v $=$ A. subcordata var. villosa; $A$. ori $=$ A. orientalis; $A$. dol $=A$. dolichocarpa; $A$. dja = A. djavanshirii; A. lag $=A$. longiflorescentia; A. New $=$ A. hyrcana

A. glutinosa subsp. antitaurica formed a group and A. glutinosa subsp. barbata joined them.

In another branch, we found two subbranches: one of them was small and contained A. dolichocarpa, while another sub-branch was large and consisted of two groups. A. subcordata var. subcordata and $A$. orientalis clustered as a group, but the other group had A. longiflorescentia and A. hyrcana as a group and A. subcordata var. villosa joined them.

CA-joined plot proved that each taxon had distinct morphological feature(s), which was useful in identification of them. For example, presence of indumentum on petiole, bud and 
leaf were prominent traits for A. hyrcana and angle of leaf base and female catkin width for A. longiflorescentia (Fig. 4).

\section{Molecular analysis}

The results of molecular analysis given by the Bayesian method, confirmed that Alnus genus is a monophyletic group and that there were two separate clades (I and II) for this genus in Iran (Fig. 5). The main clade I is divided into sub-clades A and B. Sub-clade A includes A. glutinosa subspecies (including A. glutinosa subsp. glutinosa, A. glutinosa subsp. barbata, and A. glutinosa subsp. antitaurica)

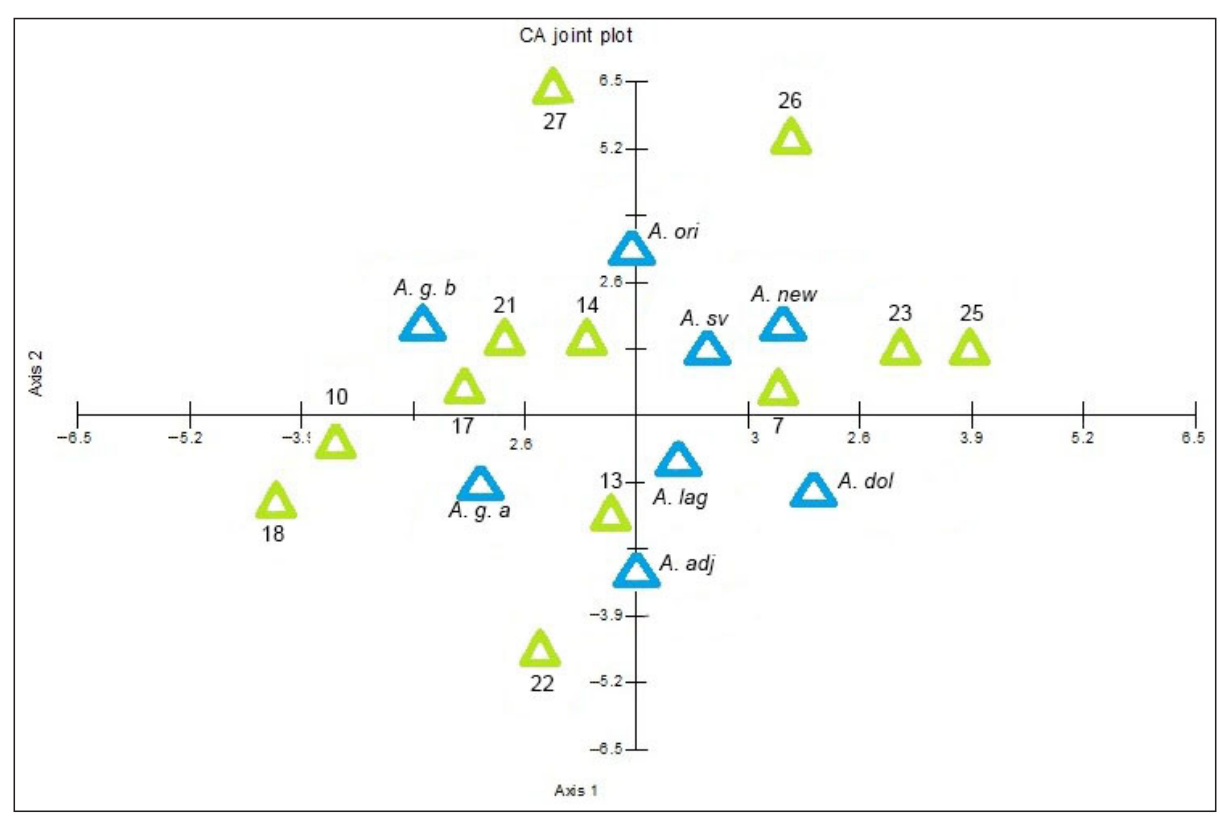

Fig. 4. CA-joined plot of the studied taxa and their morphological variables. Abbreviation: A. g.g = A. glutinosa subsp. glutinosa; A. g.b = A. glutinosa subsp. barbata; A. g.a = A. glutinosa subsp. antitaurica; A. s.s = A. subcordata var. subcordata; A. s.v = A. subcordata var. villosa; A. ori = A. orientalis; A. dol = A. dolichocarpa; A. dja $=$ A. djavanshirii; A. lag $=$ A. longiflorescentia $;$ A. New $=$ A. hyrcana

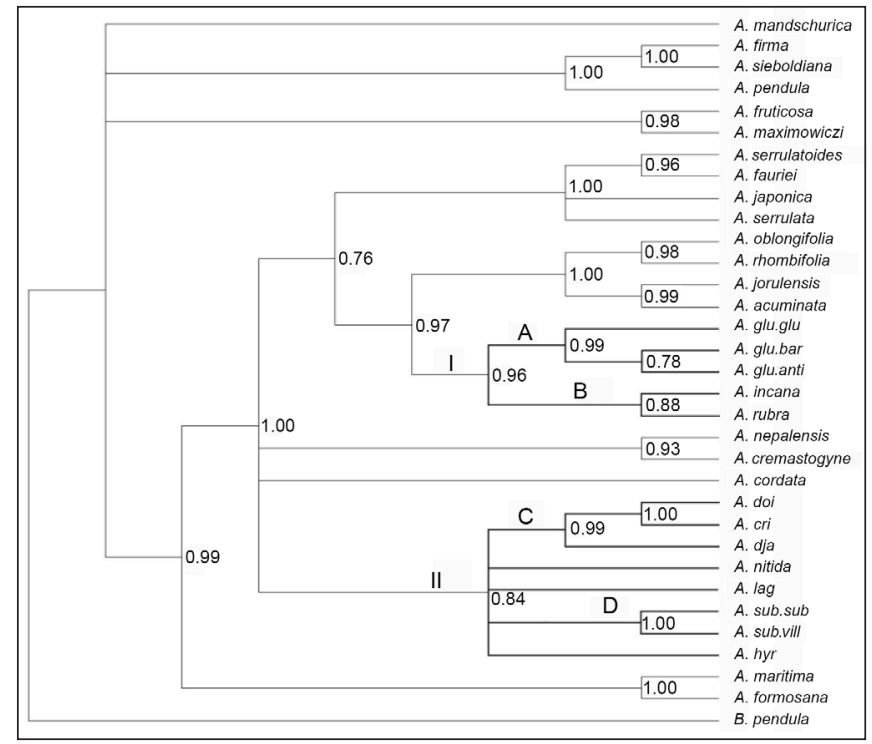

Fig. 5. Cladogram resulting from molecular analysis (Bayesian method). Abbreviations: A. glu.glu $=$ A. glutinosa subsp. glutinosa; A. glu.bar $=A$. glutinosa subsp. barbata; A. glu.anti $=$ A. glutinosa subsp. antitaurica; $A$. sub.sub $=$ A. subcordata var. subcordata; A. sub.vill = A. subcordata var. villosa; A. ori $=$ A. orientalis; $A$. doli $=$ A. dolichocarpa; $A$. dja $=$ A. djavanshirii; $A$. lag $=A$. longiflorescentia; $A$. hyr $=$ A. hyrcana 
and sub-clade B includes $A$. incana and A. rubra (not native to Iran) with a statistical support of 0.96. The main clade II is also divided into sub-clades $\mathrm{D}$ and $\mathrm{C}$. Sub-clade $\mathrm{C}$ contains A. orientalis, A. dolichocarpa, and A. djavanshirii (with a statistical support of 0.88 ). A. djavanshirii was also found to be close to A. orientalis and A. dolichocarpa (with a statistical support of 0.99). Sub-clade D contained A. subcordata var. subcordata and A. subcordata var. villosa (with a statistical support of 0.89). Two new species, A. hyrcana and A. longiflorescentia, were clustered far from the other taxa. In addition, molecular analysis using the raxml method also indicated that Alnus was a monophyletic group and Alnus taxa of Iran were placed into two sepa- rate clades (I and II) (Fig. 6). Clade I includes A. subcordata var. villosa, A. subcordata var. subcordata, A. orientalis, A. dolichocarpa, and A. djavanshirii. Two new species, A. hyrcana and $A$. longiflorescentia, were placed far from the other taxa. A. glutinosa subsp. glutinosa, A. glutinosa subsp. barbata, and A. glutinosa subsp. antitaurica were grouped in clade II.

\section{Descriptions of new species}

Based on the results of morphological and phylogenetic studies, two new species were identified in Iran. The main morphological differences between these new species with other closet species of Alnus are listed in Table 6. The morphology and geographical details of these species were given here:

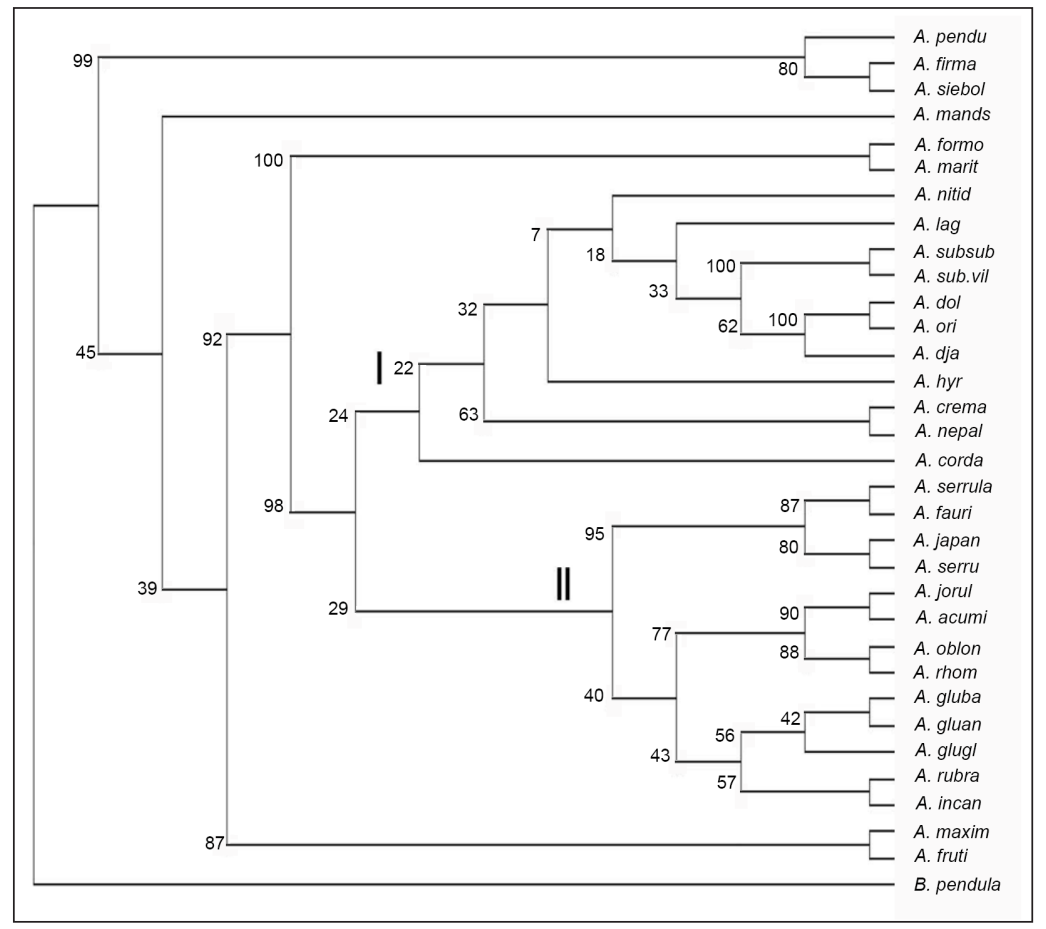

Fig. 6. Cladogram resulting from molecular analysis (RAXML method). Abbreviations: $A \cdot$ glu.glu $=A$. $g l u t i-$ nosa subsp. glutinosa; A. glu. bar $=$ A. glutinosa subsp . barbata; A. glu.anti $=$ A. glutinosa subsp. antitaurica; $A$. sub.sub $=$ A. subcordata var. subcordata; $A$. sub. vill $=$ A. subcordata var. villosa; A. ori $=$ A. orientalis; $A$. doli $=$ A. dolichocarpa; A. dja $=$ A. djavanshirii; $A$. lag $=$ A. longiflorescentia; . hyr = A. hyrcana

Table 6. Comparison between the new species of Alnus and the species close to them

\begin{tabular}{ccccc|c|c}
\hline Characters & A. hyrcana & A. longiflorescentia & A. dolichocarpa & A. orientalis & A. subcordata var. villosa \\
\hline Braches indumentum & Pubescent & Glabrous & Puberulent & Glabrous & Puberulent \\
\hline Leaf base angle & 125 & 124 & 150 & 104 & 112 \\
\hline Leaf margin shape & Serrulate & Large lobed dentate & Double serrate & $\begin{array}{c}\text { Large lobed } \\
\text { dentate }\end{array}$ & Serrate \\
\hline Leaf blade length & $10.9 \mathrm{~cm}$ & $14.4 \mathrm{~cm}$ & $13.1 \mathrm{~cm}$ & $12.7 \mathrm{~cm}$ & $8.9 \mathrm{~cm}$ \\
\hline Leaf blade width & $6.9 \mathrm{~cm}$ & $8.7 \mathrm{~cm}$ & $9.3 \mathrm{~cm}$ & $6.4 \mathrm{~cm}$ & $5.5 \mathrm{~cm}$ \\
\hline Cone length & $2.3 \mathrm{~cm}$ & $3.4 \mathrm{~cm}$ & $2.8 \mathrm{~cm}$ & $2 \mathrm{~cm}$ & $2.1 \mathrm{~cm}$ \\
\hline
\end{tabular}


Alnus hyrcana: Sharifnia \& Gholamiterojeni, sp. nova (Figs. 7 and 8).

Type: Iran, Golestan National Park, $37^{\circ} 23^{\prime} 43.62^{\prime \prime} \mathrm{N}, 55^{\circ} 48^{\prime} 1.5^{\prime \prime} \mathrm{E}, 471 \mathrm{~m}, 20$ October 2015 Sharifnia \& Gholamiterojeni 16720 (holotype IAUNT).

A tree of about $10 \mathrm{~m}$ in height, deciduous, young twigs and buds tomentose. Leaves ovate, $11.2-16.2 \mathrm{~cm}$ long and 10.6-11.2 cm broad, acute, semi-cordate at the base, ser- rulate at the margin, with $10-12$ pairs of veins, tomentose on the upper surface, more densely hairy on the lower surface; petioles $1.5-2.4 \mathrm{~cm}$ long, pubescent. Male inflorescence cluster with 4 catkins, $1.8-2.8 \mathrm{~cm}$ long and $3-4 \mathrm{~mm}$ wide; stalk $0.5-1.2 \mathrm{~cm}$ long. Female inflorescence cluster with 2-3 conelike catkins; catkins ovate, $2.2-2.4 \mathrm{~cm}$ long and $1.4-1.5 \mathrm{~cm}$ wide; peduncle $1-1.3 \mathrm{~cm}$ long. Seed winged.

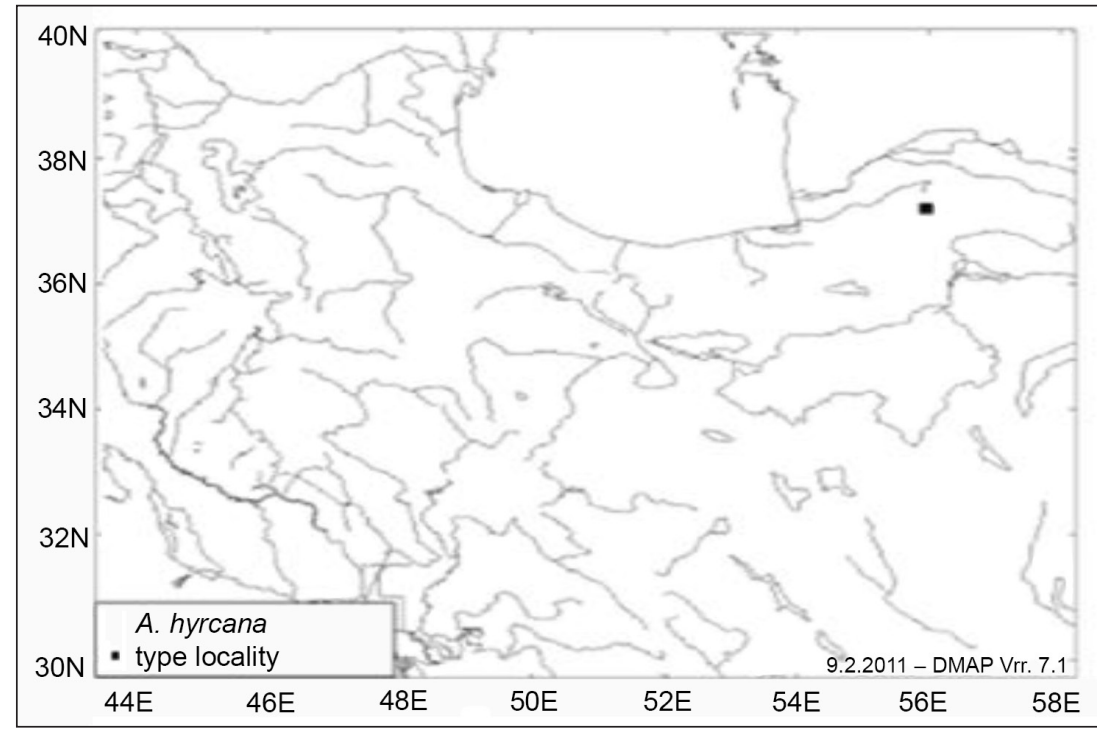

Fig. 7. Distribution map of Alnus hyrcana in Iran

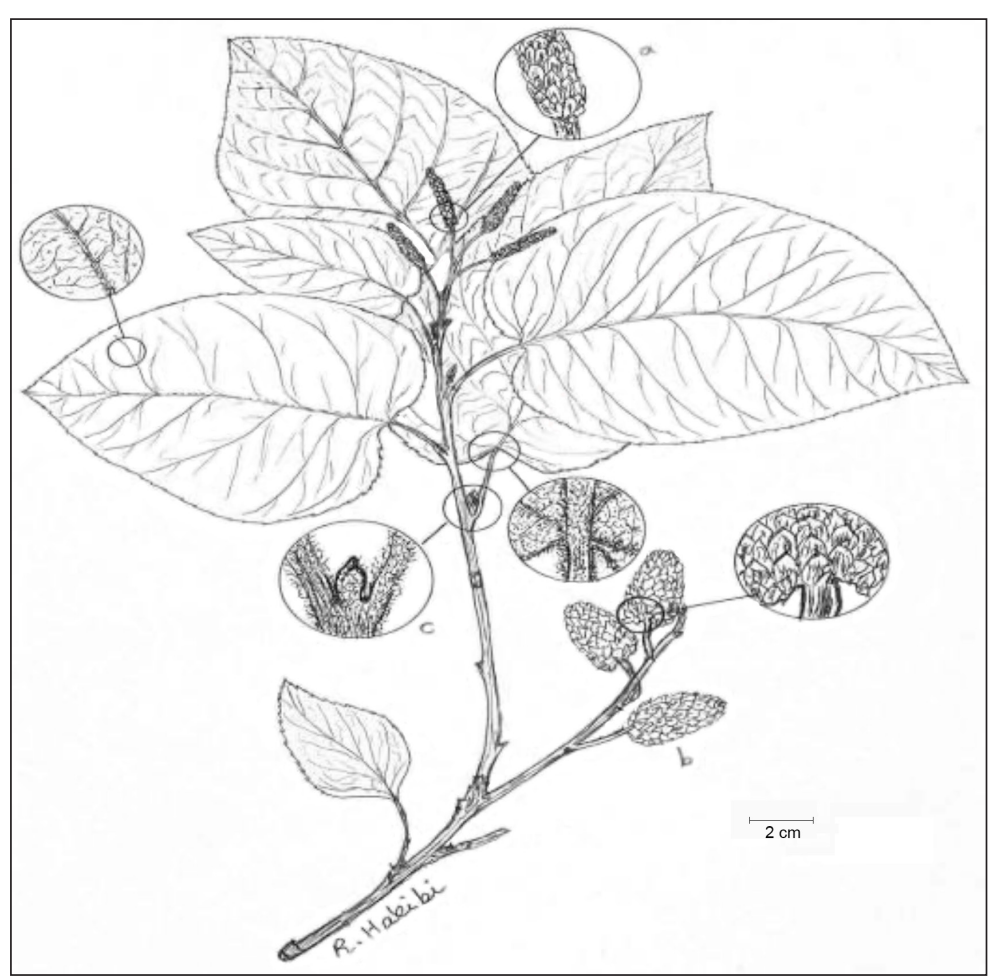

Fig. 8. A. hyrcana. a: male catkins. b: female cone-like catkin. c: bud 
Alnus longiflorescentia: Sharifnia \& Gholamiterojeni, sp. nova (Figs. 9 and 10).

Type: Iran, Golestan Province, Gorgan, Ziarat, $36^{\circ} 7^{\prime} 7.7^{\prime \prime} \mathrm{N}, 53^{\circ} 3^{\prime} 20.8^{\prime \prime} \mathrm{E}, 640 \mathrm{~m}, 16$ September 2015 Sharifnia \& Gholamiterojeni 16719 (holotype IAUNT).
A tree of about $10 \mathrm{~m}$ in height, deciduous, young twigs; buds and petioles puberulent. Leaves elliptic-ovate, $11.2-16.2 \mathrm{~cm}$ long and $6.8-9.8 \mathrm{~cm}$ wide, usually long-acuminate at apex, asymmetric cordate to cuneate at the base, at the margin with large teeth in the upper third

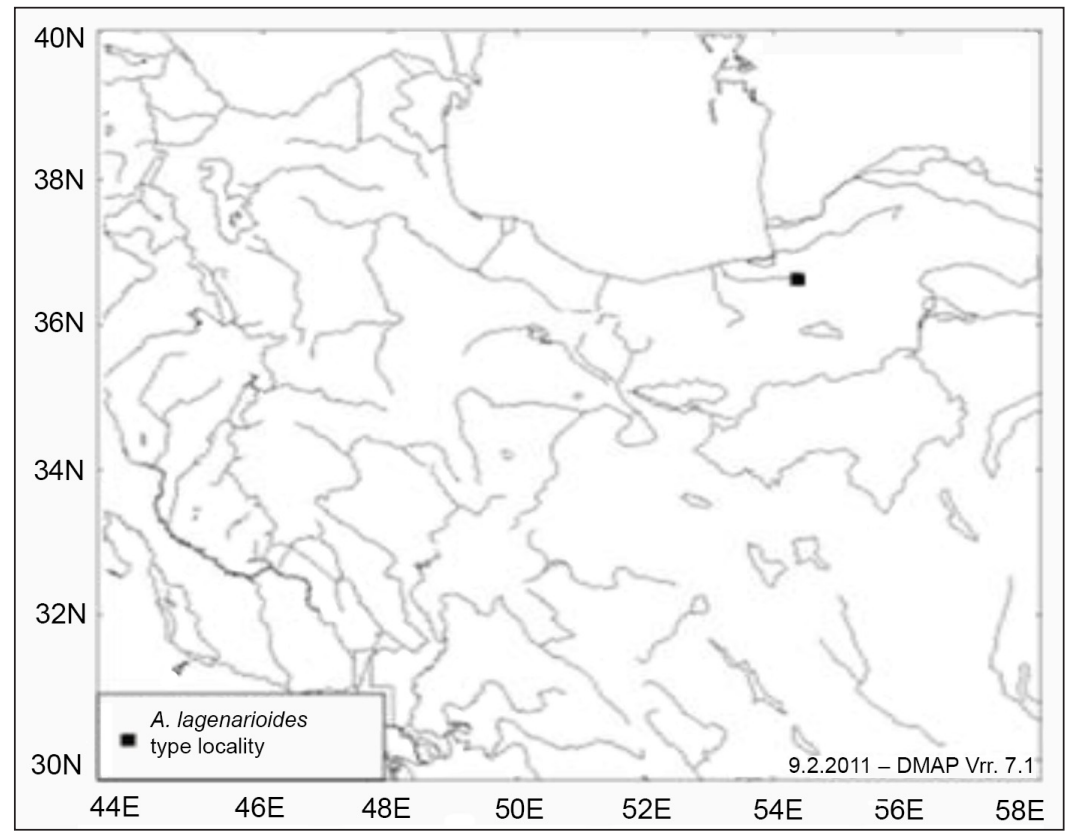

Fig. 9. Distribution map of A. longiflorescentia in Iran

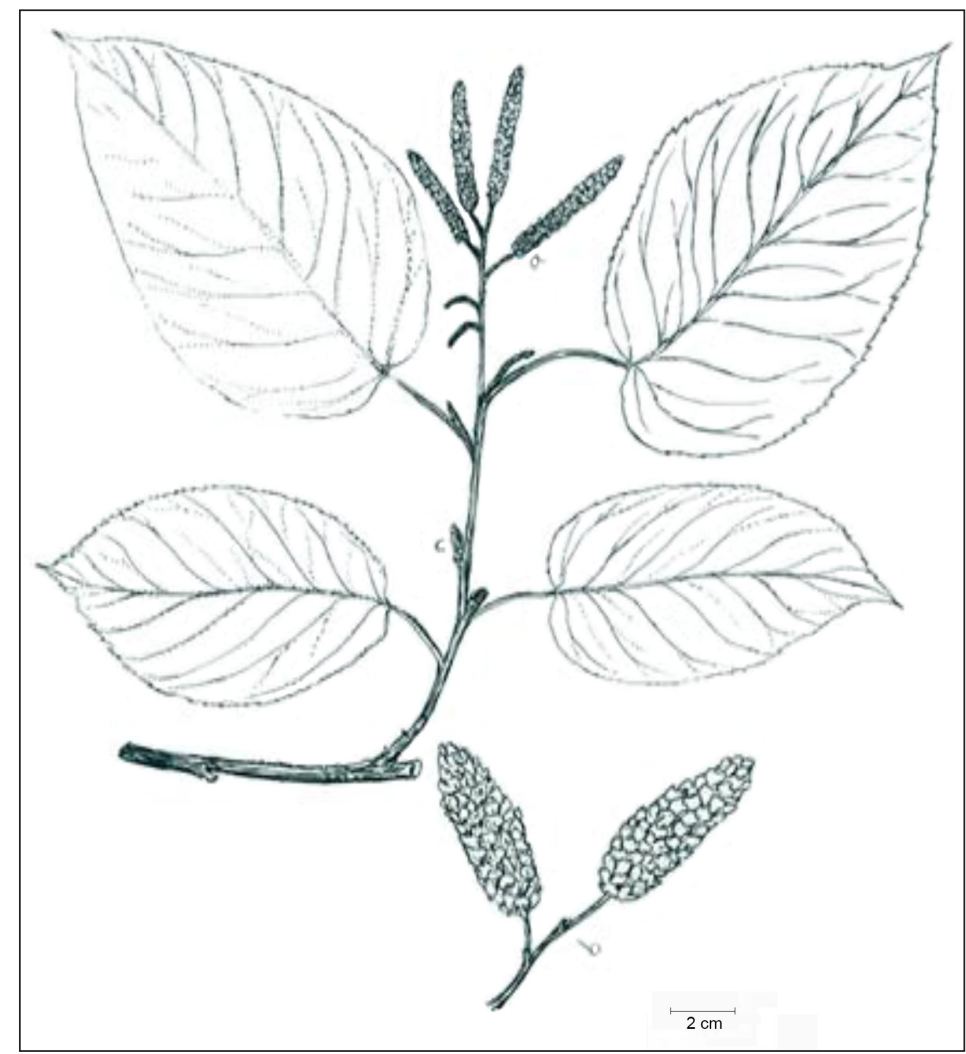

Fig. 10. Alnus longiflorescentia. a: male catkins. b: female cone-like catkin. c: bud 
of the upper half, with sparse hairs on the upper surface, glabrous on the lower surface with less hairs on the veins and presence of tufts of hairs in the axil of veins, with 9-14 pairs of lateral veins; petioles with long hairs, $1.5-2.4 \mathrm{~cm}$ long. Male inflorescence clusters with $4-5$ catkins, catkins $3-4.7 \mathrm{~cm}$ long and 3-4 mm wide; stalk $0.5-1 \mathrm{~cm}$ long. Female inflorescence large, cone-like, cylindrical, $2.5-4.2 \mathrm{~cm}$ long and $1-1.3 \mathrm{~cm}$ wide; peduncle $1-2.8 \mathrm{~cm}$ long. Seeds winged.

\section{DISCUSSION}

In the current study, we used morphological and molecular data for the delimitation of species in Iranian Alnus species. For morphological study, 28 distinct characteristics were studied; the selection of these features was based on previous morphological studies of the genus (Chang et al., 2005; Banaev, Bazunt, 2007; Eom et al., 2011; Basic et al., 2014; Poljak et al., 2014).

The ANOVA test revealed significant differences for most morphological characteristics. The obtained results of clustering morphological study showed that ten taxa of seven Alnus species grow naturally in Iran. Some of them (A. glutinosa and A. subcordata) have infraspecific taxonomic ranks: A. glutinosa subsp. antitaurica, A. glutinosa subsp. barbata, A. glutinosa subsp. glutinosa, A. subcordata var. villosa, and $A$. subcordata var. subcordata, while the rest - A. dolichocarpa, A. djavanshirii, and A. orientalis - are monotypic. In addition, two species, A. hyrcana and A. longiflorescentia, are introduced as new species from Iran.

The new species were compared morphologically with other Iranian taxa of the genus. This comparison showed differences in some characteristics including the angle of the leaf base, leaf margin, the length of leaf blade, the width of leaf blade, the length of the female catkin, and the presence of hair on young twigs.

We compared these new species (A. hyrca$n a$ and $A$. longiflorescentia) with other similar Iranian taxa and found that $A$. longiflorescentia differed from other species by bigger female inflorescence. Beside, A. hyrcana is separated from the other species by the largest amount of hair on young twigs, buds, leaves, and petioles. A. orientalis and A. djavanshiri are morphologically close to A. subcordata.

For phylogeny study, we selected the ITS marker, because previous studies revealed that ITS was a good phylogeny marker for the genus. For example, Chen and Li (2004) used ITS sequences to assess the phylogenetic relationships of Alnus species. Moreover, Ren et al. (2010) used the nuclear ITS marker and three chloroplastic markers ( $\mathrm{rbc} \mathrm{L}$, mat $\mathrm{K}$, trnH- psbA) to assay investigate 23 Alnus species throughout the world. Results of their study showed that the separability of rbcL, matK, trnH-psbA, and ITS in the species level was $10 \%, 31.25 \%, 63.6 \%$ and $76.9 \%$, respectively. Therefore, the ITS sequence is the most powerful molecular marker to identify Alnus species.

There are many discussions about the taxonomic status of genus Alnus. Linnaeus (1753) considered Alnus as part of genus Betula, but Murai (1964) identified Alnus as a genus that is distinct from Betula. Several morphological (Crane, 1989; Furlow, 1990) and molecular (Bousquet et al., 1992; Savard et al., 1993) studies confirmed separation of Alnus from Betula.

Based on the phylogeny analyses, we found that Alnus taxa were a monophyletic group and genus Betula could be considered as a sister group for Alnus. Our findings agreed with a previous study of Navarro et al. (2003). They evaluated phylogeny of 19 species of Alnus and found that all species together made a monophyletic group close to Betula.

The studied taxa were separated in Bayesian cladogram of ITS data and created similar results with morphological investigation. Furthermore, ITS data confirmed the presence of two new species (A. hyrcana and A. longiflorescentia) in Iran, therefore it is clear that 10 taxa of Alder species occur in the country's Hyrcanian forest. These results agreed with Zare and Amini (2012) study and proved the existence of A. dolichocarpa, A. orientalis, and A. djavanshirii in Iran, and contradicted some similar previous studies, such as Browics (1972) and Hoseinzadeh et al. (2016). 


\section{CONCLUSIONS}

Alnus is a problematic genus of Betulaceae, which grow widely in different parts of the world, including Iran. There are many discussions about the number of species of the genus in the country and therefore we conducted morphological and molecular ITS studies for the delimitation of species of Alnus in Iran. A morphological study proved the existence of ten taxa in Iran, with two new species. Moreover, molecular phylogenetic data revealed the genus is monophyletic and had ten taxa, including five monotypic species and five species with infraspecific ranks, three subspecies and two varieties. The new species had prominent morphological traits, which were useful in species identification.

\section{ACKNOWLEDGEMENTS}

The authors thank Habib Zare from Nowshahr Botanical Garden for consulting and Mrs. Habibi for drawing images of the new species.

Received 9 February 2019 Accepted 10 June 2019

\section{References}

1. Banaev EV, Bezant V. Study of natural hybridization between Alnus incana (L.) Moench. and Alnus glutinosa (L.) Gaertn. J For Sci. 2007; 53: 66-73.

2. Basic N, Selimovic E, Pustahija F. Morphological identification of nothospecies Alnus $\times p u$ bescens Tausch. and their new localities in central Bosnia. Works of the Faculty of Forestry University of Sarajevo. 2014; 1: 15-24.

3. Boissier E. Betulaceae. In: Georg H, editor. Flora Orientalis, vol. 4. Geneva. 1879; 1179-80.

4. Bousquet J, Strauss SH, Li P. Complete congruence between morphological and rbcLbased molecular phylogenies in birches and related species (family Betulaceae). Mol Biol Evol. 1992; 9: 1076-88.
5. Browicz K. Betulaceae. In: Rechinger KH, editor. Flora Iranica. Graz. 1972: 96.

6. Chang KS, Chang CS, Park JS. Taxonomic reconsideration of Alnus hirsuta var. hirsuta and A. hirsuta var. sibirica in Korea. Bull Seoul Natal Univ Arbor. 2005; 25: 82-88.

7. Chen Z, Li J. Phylogenetics and biogeography of Alnus (Betulaceae) inferred from sequences of nuclear ribosomal DNA ITS region. Int J Plant Sci. 2004; 165(2): 325-35.

8. Crane PR. Early fossil history and evolution of the Betulaceae. In: Evolution, systematics, and fossil history of the Hamamelidae. Vol. 2: 'Higher' Hamamelidae. Crane PR, Blackmore S, editors. Oxford: Clarendon; 1989; 87-116.

9. Douzery EJP, Pridgeon AM, Kores P, Linder HP, Kurzeweil H, Chase MW. Molecular phylogenetics of Disa (Orchidaceae), a contribution from nuclear ribosomal ITS sequences. Am J Bot. 1999; 86: 887-99.

10. Eom HJ, Chang KS, Kim H, Chang CS. Notes on a new overlooked taxon of Alnus (Betulaceae) in Korea. Forest Sci Technol. 2011; 7(1): 42-6.

11. Frodin DG, Govaerts R. World checklist and bibliography of Fagales. Royal Botanical Gardens Kew: 1998; 17-23.

12. Furlow JJ. The systematics of the American species of Alnus (Betulaceae). Rhodora. 1979; 81(826): 151-248.

13. Furlow JJ. The genera of Betulaceae in the Southeastern United States. J Arnold Arboreum. 1990; 71: 1-67.

14. Hoseinzadeh CA, Yousefzadeh H, Shayanmehr F, Jalali SG, Zare H, Tippery NP. Molecular taxonomy of Hyrcanian Alnus using nuclear ribosomal ITS and chloroplast trnHpsbA DNA barcode markers. Syst Biodivers. 2016; 14(1): 88-101.

15. Hu WC, Wang MH. Antioxidative activity and anti-inflammatory effects of diarylheptanoids isolated from Alnus hirsuta. J Wood Sci. 2011; 57: 323-30. 
16. Lee MW, Tanaka T, Nonaka GI, Nishioka I. Dimeric ellagitannins from Alnus japonica. Phytoehtmistry. 1992; 31: 2835-9.

17. Linnaeus C. Species plantarum. Stockholm: 1753.

18. Kuzeneva OI. Betulaceae. In: Komarov VL, editor Flora of the U.S.S.R. vol. 5. Moskva \& Leningrad. 1936; 269-319.

19. Mobayen S. Flora of Iran: Vascular Plants. University of Tehran Press. 1985; 2: 73-87 Persian.

20. Murai S. Phytotaxonomical and geobotanical studies on gen. Alnus in Japan. III. Taxonomy of whole world species and distribution of each sect. Bull Gov Forest Exp Sta. 1964; 171: $1-107$.

21. Navarro E, Bousquet J, Moiroud A, Munive A, Piou D, Normand P. Molecular phylogeny of Alnus (Betulaceae), inferred from nuclear ribosomal DNA ITS sequences. Plant Soil 2003; 254(1): 207-17.

22. Novaković M, Stanković M, Vučković I, Todorović N, Trifunović S, Tešević V, Vajs V, Milosavljević S. Diarylheptanoids from Alnus glutinosa bark and their chemoprotective effect on human lymphocytes DNA. Planta Med. 2013; 79: 499-505.

23. Park D, Kim HJ, Jung SY, Yook CS, Jin C, Lee YS. A new diarylheptanoid glycoside from the stem bark of Alnus hirsuta and protective effects of diarylheptanoid derivatives in human HepG2 cells. Chem Pharm Bull (Tokyo). 2010; 58(2): 238-41.

24. Podani J. Introduction to the Exploration of Multivariate Biological Data. Leiden, 2000.

25. Poljak I, Idzojtic M, sapic I, Vukelic J., Zebec M. Population variability of grey (Alnus incana (L.) Moench) and black alder (A. glutinosa (L.)
Gaertn.) in the Mura and Drava region according to the leaf morphology. J Foresty Society of Croatia. 2014; 138(1-2): 7-16.

26. Ren BQ, Xiang XG, Chen ZD. Species identification of Alnus (Betulaceae) using nrDNA and cpDNA genetic markers. Mol Ecol Resour. 2010; 10(4): 594-605.

27. Sagheb-Talebi K. Forests of Iran. Research Institute of Forests and Rangelands. 2004; 30-5. Persian.

28. Sati SC, Sati N, Sati OP. Bioactive constituents and medicinal importance of genus Alnus. Pharmacogn Rev. 2011; 5(10): 174-83.

29. Savard L, Michaud M, Bousquet J. Genetic diversity and phylogenetic relationships between birches and alders using ITS, 18S rRNA and $\mathrm{rbcL}$ gene sequences. Mol Phylogenet Evol. 1993; 2: 112-8.

30. Shayan P, Borji H, Eslami A, Zakeri S. Isolation of DNA from a single Helminth using new developed Kit in Iran and ITS PCR analysis. Iran J Parasitol. 2007; 2(2): 34-9.

31. Shayanmehr F, Jalali G, Colagar AH, Zare H, Yousefzadeh $\mathrm{H}$. Morphological variations of genus Alnus in Iran: assessment of five new taxa. Taxon Biosyst J. 2014; 6(18): 45-64.

32. Yaltrik Y. Betulaceae. In: Davis P. H. (ed.), Flora of Turkey, vol. 7. Edinburgh. 1982; 688-94.

33. Zare H. Betulaceae, Flora of Iran. Research Institute of Forests and Rangelands. 2016; 10-31. Persian.

34. Zare H, Amini T. A review of the genus Alnus Mill. in Iran, new records and new species. Iran J Bot. 2012; 18(1): 10-21.

35. Zohary M. Geobotanical foundation of the Middle East. Stuttgart: Gustav, Fische Verlag; 1973. 
Tahereh Gholamiterojeni, Fariba Sharifnia,

Taher Nejadsattari, Mostafa Assadi, Seyed

Mohammad Mehdi Hamdi

BERŽINIŲ GENTIES (BETULACEAE) JUO-

DALKSNIO (ALNUS) APŽVALGA IRANE

NAUDOJANTIS MOLEKULINIAIS ITS ŽYME-

NIMIS IR MORFOLOGINĖMIS CHARAKTERISTIKOMIS

\section{Santrauka}

Alksniai (Alnus) yra beržinių (Betulaceae) genties augalai, pasaulyje jų yra daugiau nei 29 rūšys. Irane aptinkami aštuoni šiaurinèje Elburso kalnyno dalyje, Hirkanijos miškuose, natūraliai augantys šios genties taksonai. Tyrimo metu analizuotos morfologinès charakteristikos ir filogenetiniai ryšiai tarp 31 Irane augančios alksninių genties populiacijos. Morfologinei analizei buvo pasitelkti ITS regiono žymenys - tirtos 28 kokybinès ir kiekybinès žymės. Statistinei analizei naudotos MVSP, SPSS, MrBayes, RAXMLGUI, Mesquite 2.71 ir Modeltest 3.7 kompiuterinès programos. Tirtų taksonų morfologinès savybès itin varijavo - ANOVA testas atskleidè statistiškai reikšmingus skirtumus. Labiausiai skyrèsi lapo pagrindo kampas, lapo forma ir ilgis, lapo galo plotis, vaisių ilgis, lapkočio, jaunų šakelių bei pumpurų plaukuotumas. Analizuoti taksonai buvo išskirstyti pagal PCA ir PCO morfologinius žymenis. CA jungimas rodo, kad kiekvienas taksonas turi specifinę morfologinę savybę, naudingą identifikavimui. Filogenetinè analizė atskleidè, kad alksninių gentis yra monofiliné; sudaryta taksonų filogenetinè dendrograma. Remiantis gautais morfologiniais duomenimis bei ITS rezultatais, Irane paplitusi alksninių gentis suskirstyta ị 10 taksonų ir įtrauktos dvi naujos rūšys - A. hyrcana ir A. longiflorescentia, aptiktos Hirkanijos miškuose.

Raktažodžiai: Alnus, Hirkanijos miškai, Iranas, ITS, naujos rūšys, morfologija 